\title{
Effects of montelukast (MK-0476), a potent cysteinyl leukotriene receptor antagonist, on bronchodilation in asthmatic subjects treated with and without inhaled corticosteroids
}

Theodore F Reiss, Christine A Sorkness, William Stricker, Albert Botto, William W Busse, Sudeep Kundu, Ji Zhang

\begin{abstract}
Background - Cysteinyl leukotriene release in association with airway inflammation is a feature of clinical asthma. The acute effects of montelukast (MK-0476), a potent, orally administered, specific cysteinyl leukotriene receptor antagonist, on airways obstruction was assessed in patients with mild to moderately severe asthma.

Methods - Twenty two asthmatic subjects were randomised to receive montelukast, $100 \mathrm{mg}$ or $250 \mathrm{mg}$, or placebo in a double blind, three period, crossover trial. Ten of the patients were using concomitant inhaled corticosteroids.

Results - Montelukast increased the forced expiratory volume in one second $\left(\mathrm{FEV}_{1}\right)$ from predose baseline values compared with placebo, the percentage point differences between montelukast and placebo being $8.6 \%(95 \%$ CI 3.6 to 13.6$)$ and $8.5 \%$ (95\% CI 3.5 to 13.5$)$ for the $100 \mathrm{mg}$ and $250 \mathrm{mg}$ doses, respectively.

Conclusion - Single oral doses of montelukast $100 \mathrm{mg}$ and $250 \mathrm{mg}$ produced significant increases in $\mathrm{FEV}_{1}$ irrespective of the concurrent use of inhaled corticosteroids in asthmatic subjects with airflow limitation.
\end{abstract}

(Thorax 1997;52:45-48)

Keywords: cysteinyl leukotriene receptor antagonist, montelukast (MK-0476), bronchodilation.

Madison, Wisconsin,

USA

C A Sorkness

Clinical Research of the Ozarks, Rolla,

Missouri, USA

W Stricker

Department of Medicine, University of Wisconsin School of Medicine, Madison,

Wisconsin, USA

W W Busse

Correspondence to: Dr T F Reiss, Merck Research Laboratories, RY 33-648, PO Box 2000, Rahway, New Jersey 07065 , USA

Received 5 March 1996 Returned to authors 29 April 1996

Revised version received

10 July 1996

Accepted for publication

1 August 1996
Methods

PATIENTS

Healthy non-smoking (for at least one year, no more than five pack years) male and female asthmatic patients aged 18-54 years participated in the study. Patients were required to have a forced expiratory volume in one second $\left(\mathrm{FEV}_{1}\right)$ between $50 \%$ and $80 \%$ of predicted values, with at least a $15 \%$ increase in $\mathrm{FEV}_{1}$ within 30 minutes of inhaling salbutamol $(180 \mu \mathrm{g})$ at the prestudy visit.

Patients were allowed to use a constant dose of inhaled corticosteroids (initiated at least four weeks prior to the study). Long acting antihistamines and $\beta$ agonists (inhaled or oral), disodium cromoglycate, and oral corticosteroids were excluded; inhaled salbutamol, used as needed, was permitted between dosing days.

Patients were excluded if an upper respiratory infection or treatment with an investigational drug had occurred during four weeks before the start of the trial. The protocol was approved by the respective institutional review boards and written informed consent was obtained from the study subjects.

\section{STUDY DESIGN}

Patients received either placebo or montelukast, $100 \mathrm{mg}$ or $250 \mathrm{mg}$, on three separate treatment days in a randomised, double blind, crossover manner. Treatment periods were separated by at least 72 hours. Prior to the start of the study the following medications were withheld: short to intermediate acting antihistamines (48 hours); theophylline ( 24 hours); inhaled $\beta$ agonists (six hours). Patients took their normal inhaled corticosteroids in the morning, at least one hour before the study medication.

Administration of the study drug and spirometric measurements were performed for each patient at the same time of day during all three treatment periods $(0700 \pm 1$ hour $)$. Spirometric testing was performed 30 and 15 minutes before the medication was given and hourly for six hours afterwards. A second dose was then administered (to assure that subsequent salbutamol administration occurred at peak plasma concentrations 3-5 hours after dosing). Three hours later, patients received two puffs $(180 \mu \mathrm{g})$ of salbutamol which was repeated 20 and 40 minutes later. Spirometric parameters 
Table 1 Demographic data

\begin{tabular}{|c|c|c|c|c|}
\hline Patient no & Sex & Age (years) & $\begin{array}{l}F E V_{1} \\
(\% \text { predicted })^{*}\end{array}$ & $\begin{array}{l}\text { Concomitant daily } \\
\text { asthma therapy }\end{array}$ \\
\hline 1 & Female & 51 & 63 & BDP $400 \mu \mathrm{g}$, Theo, $\mathrm{S}$ \\
\hline 2 & Male & 18 & 59 & BDP $200 \mu \mathrm{g}, \mathrm{S}$ \\
\hline 3 & Male & 50 & 79 & BDP $200 \mu \mathrm{g}, \mathrm{S}$ \\
\hline 4 & Male & 45 & 60 & BDP $400 \mu \mathrm{g}$, Theo, $\mathrm{S}$ \\
\hline 5 & Male & 21 & 69 & \\
\hline 6 & Male & 29 & 66 & Triam $1200 \mu \mathrm{g}$, Theo, $\mathrm{S}$ \\
\hline 7 & Male & 21 & 78 & BDP $400 \mu \mathrm{g}, \mathrm{S}$ \\
\hline 8 & Male & 21 & 76 & BDP $300 \mu \mathrm{g}$, Theo, $\mathrm{S}$ \\
\hline 9 & Male & 23 & 72 & Theo, $\mathrm{S}$ \\
\hline 10 & Male & 26 & 55 & $\mathrm{~S}$ \\
\hline 11 & Male & 22 & 56 & $\mathrm{~S}$ \\
\hline 12 & Male & 21 & 60 & Theo, $\mathrm{S}$ \\
\hline 13 & Female & 54 & 67 & $\mathrm{~S}$ \\
\hline 14 & Male & 21 & 65 & Theo, $\mathrm{S}$ \\
\hline 15 & Male & 19 & 67 & $\mathrm{~S}$ \\
\hline 16 & Male & 24 & 70 & $\mathrm{~s}$ \\
\hline 17 & Male & 31 & 66 & $\mathrm{~S}$ \\
\hline 18 & Male & 41 & 77 & $\mathrm{~s}$ \\
\hline 19 & Male & 18 & 75 & S \\
\hline 20 & Male & 28 & 67 & Triam $1200 \mu \mathrm{g}, \mathrm{S}$ \\
\hline 21 & Male & 31 & 55 & Flunisolide $1000 \mu \mathrm{g}$, Theo, $\mathrm{S}$ \\
\hline 22 & Male & 19 & 69 & Triam $900 \mu \mathrm{g}$, Theo, $\mathrm{S}$ \\
\hline $\begin{array}{l}\text { Median } \\
\text { (range) }\end{array}$ & & $23.5(18-54)$ & $67.0(55-79)$ & \\
\hline
\end{tabular}

$\mathrm{BDP}=$ beclomethasone $\quad$ dipropionate $; \quad$ Triam $=$ triamcinolone; Theo=theophylline; $\mathrm{S}=$ salbutamol.

* Mean of two prestudy values. was the mean of the measurements obtained 30 and 15 minutes before administration of the first dose in each treatment period. If a patient required salbutamol "rescue" during any treatment period the last recorded "pre-rescue" $\mathrm{FEV}_{1}$ value was brought forward to all subsequent time points for the purposes of computing mean values.

To determine the effect of salbutamol, comparison of the mean maximum percentage increase in $\mathrm{FEV}_{1}$ from the predose and presalbutamol baseline values were determined. The pre-salbutamol baseline was defined as the maximal $\mathrm{FEV}_{1}$ before salbutamol administration (hours 1-9).

An analysis of variance (ANOVA) model was used. The model included factors for patient, period, treatment, and corticosteroid use by treatment interaction. Model assumptions and carryover effects were assessed. ${ }^{78}$ The primary comparison between treatments - the maximum percentage change in $\mathrm{FEV}_{1}$ from baseline - was performed at a significance level of $\mathrm{p}=$ 0.05 . Formal testing within each subgroup of those using and not using inhaled corticosteroids was not performed as the study was not specifically designed to test this hypothesis.

With a sample size of 24 the study was designed to have $80 \%$ power $(\mathrm{p}=0.025$, two sided test) to detect a 0.25 litre (or $8.1 \%$ ) difference in the mean $\mathrm{FEV}_{1}$ values between treatments.

\section{Results}

Montelukast $(50 \mathrm{mg}$ ) and placebo capsules of identical appearance were supplied by Merck Research Laboratories, Rahway, NJ, USA. Patients received five capsules of the appropriate combination of active or placebo study medication at each administration.

SPIROMETRIC MEASUREMENTS

For the prestudy and predosing values (each treatment period) sets of at least three spirometric measurements were obtained on a pneumotachograph (Medical Graphics Corporation, CPF-S, St Paul, Minnesota, USA). At each time point after initial dosing at least two acceptable manoeuvres were performed. Patients were coached to achieve American Thoracic Society acceptability and reproducibility criteria; the highest $\mathrm{FEV}_{1}$ from each set of manoeuvres was selected for analysis.

DATA ANALYSIS

The ability of montelukast to cause bronchodilation was assessed by a pre-specified primary comparison of the mean maximum percentage change in $\mathrm{FEV}_{1}$ from the predose baseline value. As an additional assessment, the percentage change in $\mathrm{FEV}_{1}$ from baseline at two, three, four, and six hours after administration and the differences in the change between active treatments and placebo were determined with corresponding $95 \%$ confidence intervals. Analysis of hours 6-9 was not pre-specified and not performed. The predose baseline $\mathrm{FEV}_{1}$
Twenty men and two women with chronic asthma entered and completed the study, 10 of whom used concomitant inhaled corticosteroids (table 1). The mean predose baseline $\mathrm{FEV}_{1}$ values were comparable for each treatment period and treatment group, as well as between patients with and without concomitant inhaled corticosteroids (data not shown).

Neither period nor carryover effect was noted. In addition, no significant interaction was noted between users and non-users of inhaled corticosteroids. This observation suggests that the treatment effect was qualitatively similar in these groups. Since no interaction was observed, data from all patients were combined for analysis. During placebo treatment three patients required salbutamol rescue and in the $100 \mathrm{mg}$ treatment period two patients were rescued after the spirometric measurements at hour 5 . No patient required rescue treatment during the $250 \mathrm{mg}$ treatment period.

\section{BRONCHODILATION}

The $\mathrm{FEV}_{1}$ for all patients is shown in fig 1 as a percentage change from the predose baseline value for each study period. Figure 2 summarises the results in patients receiving concomitant inhaled corticosteroids. For all patients there was a significant difference $(p<0.05)$ between both active treatment groups and placebo in the mean (SD) maximum percentage change in $\mathrm{FEV}_{1}$ from predose baseline with values of $17.7(13.6) \%, 26.2(17.3) \%$, and 26.1 (15.5)\% for placebo, $100 \mathrm{mg}$ and 


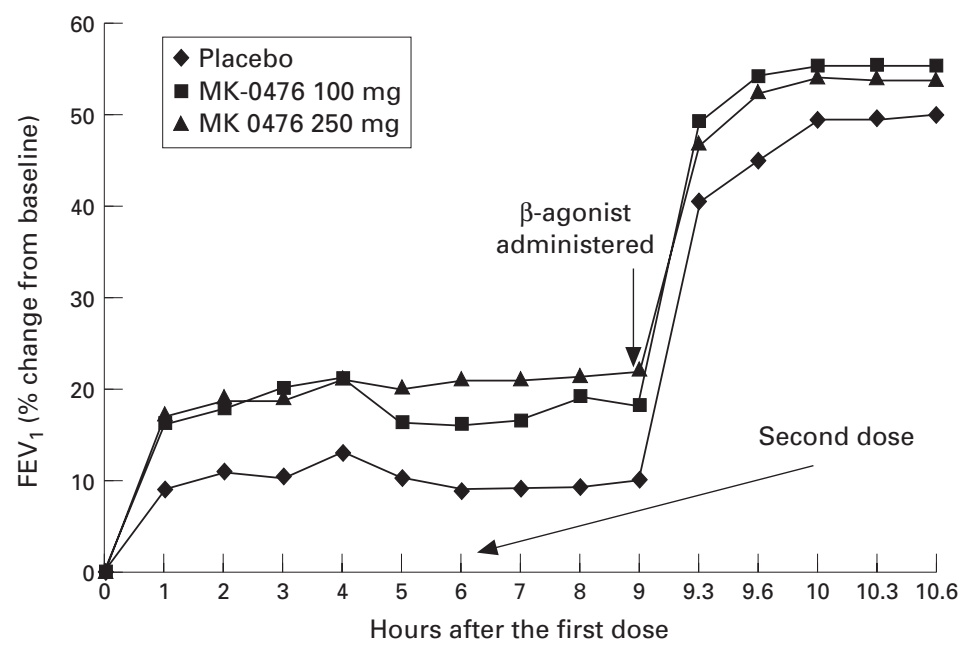

Figure 1. Mean percentage change from predose baseline value in forced expiratory volume in one second (FEV, at times after dosing during each treatment period for all patients. The second dose of study medication was administered at hour 6 and salbutamol was administered at hour 9.

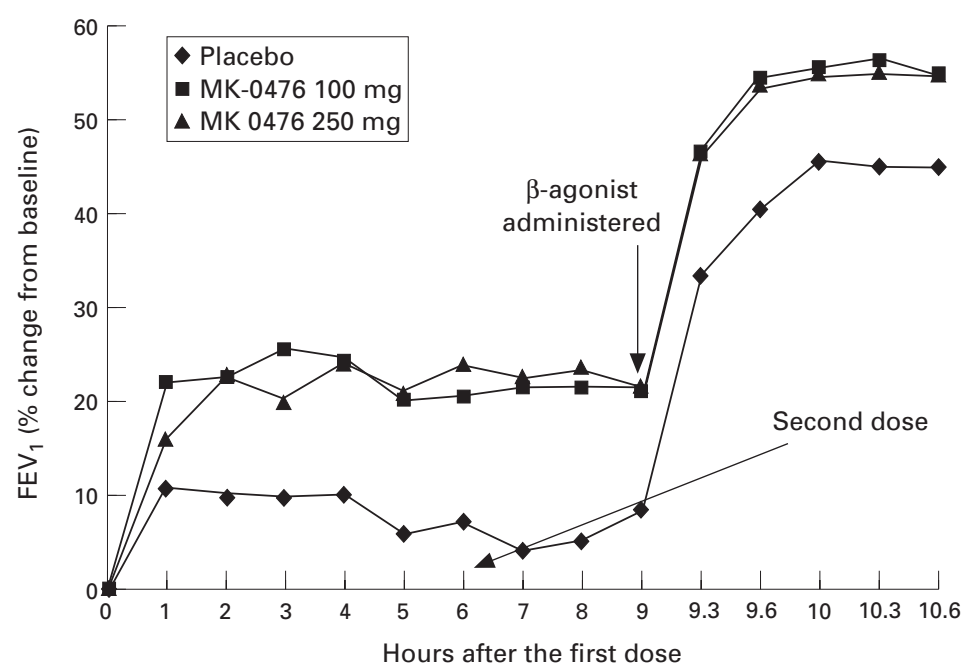

Figure 2 Mean percentage change from predose baseline value in forced expiratory volume in one second $\left(F E V_{1}\right)$ at times after dosing during each treatment period for patients receiving inhaled corticosteroids. The second dose of study medication was administered at hour 6 and salbutamol was administered at hour 9.

$250 \mathrm{mg}$ montelukast treatments, respectively. The percentage point difference from placebo was $8.6 \%(95 \%$ CI 3.6 to 13.6$)$ and $8.5 \%$ (95\% CI 3.5 to 13.5 ) for the $100 \mathrm{mg}$ and $250 \mathrm{mg}$ doses, respectively. Table 2 lists the differences between each active treatment group and $95 \%$ CI individually for hours $2-6$. Addition of the second dose did not result in added benefit over the initial six hours of observation (fig 1).

SALBUTAMOL ADMINISTRATION

Following the administration of salbutamol beginning at hour 9 , the mean maximum percentage increase in $\mathrm{FEV}_{1}$ from the predose baseline value was greater for both montelukast treatment groups compared with placebo, although the differences were not statistically significant. Additionally, the magnitude of re-
Table 2 Percentage change in forced expiratory volume in one second $\left(F E V_{1}\right)$ from predose baseline at 2, 3, 4, and 6 hours after first dose

\begin{tabular}{|c|c|c|c|}
\hline & $\begin{array}{l}\text { Mean (SD) } \\
\text { increase in } \\
\text { FEV }_{1}(\%)\end{array}$ & $\begin{array}{l}\text { Difference } \\
\text { from placebo } \\
\text { (percentage } \\
\text { points) }\end{array}$ & $\begin{array}{l}95 \% \text { CI for } \\
\text { difference from } \\
\text { placebo }\end{array}$ \\
\hline \multicolumn{4}{|l|}{ Hour 2} \\
\hline Placebo & $11.7(13.1)$ & & \\
\hline $100 \mathrm{mg}$ & $18.0(16.1)$ & 6.3 & (0.7 to 12.0$)$ \\
\hline $250 \mathrm{mg}$ & 19.1(15.5) & 7.4 & (1.8 to 13.1 ) \\
\hline \multicolumn{4}{|l|}{ Hour 3} \\
\hline Placebo & 10.1(13.9) & & \\
\hline $100 \mathrm{mg}$ & $20.7(19.1)$ & 10.6 & (4.1 to 17.1 ) \\
\hline $250 \mathrm{mg}$ & $19.4(14.9)$ & 9.3 & (2.8 to 15.8$)$ \\
\hline \multicolumn{4}{|l|}{ Hour 4} \\
\hline Placebo & $12.7(14.0)$ & & \\
\hline $100 \mathrm{mg}$ & $21.8(19.3)$ & 9.1 & (3.1 to 15.0 ) \\
\hline $250 \mathrm{mg}$ & $21.8(16.4)$ & 9.1 & (3.1 to 15.0 ) \\
\hline \multicolumn{4}{|l|}{ Hour 6} \\
\hline Placebo & $8.9(17.8)$ & & \\
\hline $100 \mathrm{mg}$ & $16.3(20.2)$ & 7.4 & (1.1 to 13.7 ) \\
\hline $250 \mathrm{mg}$ & $20.9(17.6)$ & 12.0 & (5.7 to 18.3 ) \\
\hline
\end{tabular}

sponse from the pre-salbutamol baseline values was similar in all treatment groups (fig 1).

MONTELUKAST PLASMA CONCENTRATIONS

At two and six hours after dosing plasma concentrations of montelukast for the $100 \mathrm{mg}$ and $250 \mathrm{mg}$ doses were 2.43 (1.98), 1.74 (1.12), $5.30(3.8)$, and $4.45(3.91) \mu \mathrm{g} / \mathrm{ml}$, respectively. No relationship between maximum plasma concentration and the maximum improvement in $\mathrm{FEV}_{1}$ was observed (data not shown).

\section{SAFETY}

Adverse experiences reported in this study (20 in nine patients) were generally of mild to moderate intensity, not different in frequency between treatments, and did not cause discontinuation. Specifically, no adverse events involving blood haematology, chemistry or urinalysis were noted.

\section{Discussion}

This study demonstrates the ability of montelukast to cause bronchodilation in asthmatic subjects with baseline airflow limitation. Trials with other cysteinyl leukotriene receptor antagonists have demonstrated bronchodilation after both oral and intravenous administration. For example, single intravenous doses of MK$571^{3}$ and MK-0679 4 caused bronchodilation in chronic asthmatics (approximately $15 \%$ change in $\mathrm{FEV}_{1}$ from baseline value compared with placebo), and oral administration of $40 \mathrm{mg}$ zafirlukast (ICI 204219 ) resulted in a change in $\mathrm{FEV}_{1}$ of approximately $6 \%$ from the baseline value compared with placebo. ${ }^{5}$

In this study oral doses of montelukast (100 mg and $250 \mathrm{mg}$ ) caused comparable bronchodilation. Well controlled, sufficiently powered studies using lower doses of montelukast will be needed to investigate further the relationship between dose or plasma concentration and degree of bronchodilation.

This study was not specifically designed to compare the treatment effect in patients using and not using inhaled corticosteroids. However, it was found that montelukast caused 
bronchodilation regardless of concomitant inhaled corticosteroid treatment. In vitro studies have suggested that corticosteroids may prevent the release of arachidonic acid and thus the further generation of the cysteinyl leukotrienes. ${ }^{9}$ However, a recent in vivo study has shown that, after the administration of oral corticosteroids to asthmatic patients, the cysteinyl leukotrienes may still be recovered from the airways and generated from inflammatory cells recovered from the airways. ${ }^{10}$ Thus, cysteinyl leukotriene receptor antagonists such as montelukast have the potential to provide additive clinical benefit when administered concomitantly with corticosteroids.

A large placebo response (approximately $17 \%$ increase in $\mathrm{FEV}_{1}$ from baseline) was observed in this study. This observation is consistent with the known circadian variation in airway calibre (maximal bronchoconstriction overnight and bronchodilation throughout the morning to the afternoon); study medication was given early in the morning (approximately 0700 hours) when bronchodilation begins to occur. This observation emphasises the importance of the timing of spirometric measurements during single and multiple dose studies and the importance of interpreting changes relative to placebo responses.

In conclusion, montelukast administered orally in doses of $100 \mathrm{mg}$ and $250 \mathrm{mg}$ was generally well tolerated and produced significant increases in $\mathrm{FEV}_{1}$ irrespective of the use of concomitant inhaled corticosteroids.

This study was supported by a grant from Merck Research Laboratories. The authors would like to thank Dr Dorothy Margolskee for assistance in the design of this study, Dr Alan Nies for thoughtful review of this manuscript, Susan Ruffalo for editorial assistance, and Judy Evans for typing the manuscript.

1 Manning PJ, Watson RM, Margolskee DJ, Williams V, Schwartz J, O'Byrne PM. Inhibition of exercise-induced bronchoconstriction by MK-571, a potent leukotriene D4receptor antagonist. $N$ Engl f Med 1990;323:1736-9.

2 Cloud ML, Enas GC, Kemp J, Platts-Mill T, Altman LC, Townley R. A specific $\mathrm{LTD}_{4} / \mathrm{LTE}_{4}$-receptor antagonist improves pulmonary function in patients with mild chronic asthma. Am Rev Respir Dis 1989;140:1336-9.

3 Gaddy JN, Margolskee DJ, Bush RK, Williams VC, Busse WW. Bronchodilation with a potent and selective leukoW. Bronchodilation with a potent and selective leukotriene $\mathrm{D}_{4}\left(\mathrm{LTD}_{4}\right)$ receptor antagonist $(\mathrm{MK}-571)$ in patients with asthma. Am Rev Respir Dis 1992;146:358-63 Shingo S, et al. MK-0679, acute bronchodilation with an intravenously administered leukotriene $\mathrm{D}_{4}$ antagonist, MK-679. Am Rev Respir Dis 1993;147:1442-6.

5 Hui KP, Barnes NC. Lung function improvement in asthmatics with a cysteinyl-leukotriene receptor antagonist. Lancet 1991;337:1062-3.

6 Jones TR, Labelle M, Belley M, Champion E, Charette L, Evans J, et al. Pharmacology of montelukast sodium, a potent and selective leukotriene $\mathrm{D}_{4}$ receptor antagonist. Can F Phys Pharm 1995;73:191-201.

7 Shapiro S, Wilk W. An analysis of variance test for normality (complete samples). Biometrika 1965;52:591-611.

8 Levene H. Robust test for equality of variances contributions to probability and statistics standard. Palo Alto, California: Stanford University Press, 1960:278-92.

9 Hong SL, Levine L. Inhibition of arachidonic acid release from cells as the biochemical action of anti-inflammatory

10 Dworski R, Fitzgerald GA, Oayr JA, Sheller JL. Effect of oral prednisone on airways inflammatory mediators in atopic disease. Am $\mathcal{F}$ Respir Crit Care Med 1994;149:953-9. 